\title{
Sports And Youth Development Among Universities In The West African Region
}

\author{
G. A. Deemua \\ Department Of Human Kinetics And Health Education. \\ Faculty Of Education, University Of Port Harcourt. Rivers State, Nigeria
}

\begin{abstract}
In all societies of the world, a virile youth is the bedrock on which national integration and development is predicated. The youths are the background and the building blocks of any nation. Man, today is enjoying lot of luxuries providing by the advanced technological development on one hand and facing lot of physical, mental, emotional, and social problems on the other. Collectively, all these factors affect family life, society and nation adversely in the long run. Further, advancement in recreational gadgets like T.V., Cable T.V., Video-CD games, computer games have made the child to have less interest in physical activity training resulting in some many crimes and delinquencies among children and youths. The nexus between youth and sport is development. Absolutely, sport if properly managed can be used to develop and take the youths out of the street and provide opportunities for youths to learn some of life's importance lessons for a better youthful society. The focus of this paper is to examine sports as a veritable tool for youth development. It highlighted youths skill development in sports, youths sports involvement and crime control, sports and youth restiveness and youth character development. It also presented the challenges facing the youths in sports. It concluded with recommendations which include harnessing the potential of sports by putting in place policies and programmes that can put our youth on the right path at all levels of education.
\end{abstract}

Keywords: Sports, Youth Development, Universities, West African Region.

\section{INTRODUCTION}

The youths are the future nation of tomorrow. They are also the life wire of the nation. It is a remarkable fact for any nation to change for good; it has to do with a change that involves the youth as a whole (Uzor, 2010). In all societies of the world, a virile youth is the bedrock on which national integration and development is predicated. It is a fact that the stronger the youth, the more develop a nation is. The role of the youth in nation-building process cannot be over-emphasised as countries that develop and utilise their youth in the right directions seem to be more developed. There is a confirmed connection between the prosperity of a nation and its youth development system. The late British politician and writer, Benjamin Disraeli, had rightly described 'youth of a Nation as the Trustee of Posterity' (Oputeh, 2015).

Among many approaches that can be utilised in developing our youth is sport. The potentials of sports can be harness as a veritable tool for youth development. The nexus between youth and sports is development. Sport and development refers to the use of sport as a tool for development of the youth. Precisely, developed countries like Britain, America and Germany are totally aware of the worth of their youths, hence they are regarded as an asset. Most importantly, these countries cater to the needs of their youths and provide them with education, employment, and recreational activities such as healthy and competitive environment to prepare the youth to lead the country through thick and thin. If youth is not in the right direction and is unconcerned about the future of the nation, it will become a burden for the nation and willl not play any productive role (Oputeh, 2015). 
Unfortunately, student-athletes in West African Universities currently in the sporting sector has not met the target. How many students were drawn from the university in the region to represent her country in the just concluded 2016 Olympic Games held in Rio? It is embarassing that this tested principle of utilization of the youths as agents for national development is not given proper attention. The adolescent youths in the West African Universities are rather neglected and abused. The end result of this neglect, is a demoralised and frustrated youth that easily takes to crimes, prostitution, drug abuse, cultism and kidnapping, raping among others. Some of them have been turned into thugs by the political class. Many social commentators have attributed the insurgency, Boko Haram, in the north to be unacceptable level of unemployment among the youth. In line with this opinion, Deemua (2017) asserts that sport has been seen as a major instrument of the goal of unity, political stability and equality of opportunities and to circumvene situations which may give rise to social vices and conflict.

Sport can help to solve some of the problems of modern youths by involving them in purposeful physical pursuits like recretion activities and games. When this sports and recreational activities are properly structured, organised and administered by qualified sports personnel, then can help to prevent anti-social behaviours in youth for a better society.

\section{CONCEPTS OF YOUTH AND DEVELOPMENT}

Youth is defined by Webster's New World Dictionary as, "The time of life when one is young; (a) the period between childhoods and maturity and (b) the early period of existence growth, or development. Around the world the terms "youth", adolescent, teenager" and "young person" are interchanged often meaning the same thing, occasionally differentiated. Youth generally refers to a time of life that is neither childhood nor adulthood, but rather somewhere in between (Uzor, 2010). Konokpa (as cited in Uzor, 2010) noted that youth is an alternative word to the scientifically oriented adolescent and the common terms of teen and teenager. Another common title for youth is young person or young people. Many authors give various age limits of the youth but all falling between the ages of 15 and 29 years inclusive. Development, on the other hand, is related with advancement and a progressive series of qualitative changes towards greater maturity. It is rather qualitative change in structural, functional and the behavioural aspects of the human being. Development process have greater relationship with external factors such as nutrition, activity, protection from diseases and other cutural and social influences like sports.

Ajimer, Jagter, Jagdish and Rachpal (2003), defined development specifically as the emerging and expanding the capabilities of the individual to provide greater facility in functioning such as development of motor ability from uncertain step to proficiency in games. Development, as a matter of fact is achieved through growth. Withouty proper growth probably required level of development may not be achieved at a given stage. Development refers to mental, intellectual, emotional and social aspects. Acqusition of skill and knowledge indicates development process (Ajimer, etal, 2003:59).

\section{YOUTHS SPORT SKILL DEVELOPMENT}

Skill development is an integral part of physical education and sports. A skill is a developed or acquired ability to do something well which comes from long training (Rosemary \& Ukandu, 2016). A skill can be natural or learned. The learning of motor skill is very important if one is to enjoy his participation in recreational activities and sports. Every sporting activity has some motor skill involved in its performance. For example in tennis game service, forehand and backhand, volley, lop and smash. These skills are develop as usually gained through training or experience. A skill has to do with visible result which a learner uses to show mastery. Encarta Dictionary (2009), defined skill as a seen ability to do something well usually gained through 
training or experience. Skill acquisition involves the development of a new, practical way of doing things, usually gained through experience. It also means that for a skill to be acquired, practical experience must be involved. The experience must be gained through time, and there must be visible demostration to show that the skill has been learned. The skill is supposed to improve with time and practice. Ivowi (2001) notes that skill is usually accepted to have been acquired if it can be demostrated. The importance of skill acquisition at the early stages of youth development need not be over-emphasised as no nation can match alongside other nations without the youth developing proper skills in sports. This will enable to give the youth opportunities to function effectively in the society within the limits of his ability.

The programme of activities in the Universities are designed to impact a number of skills to the students especially in sports and games. These skills are supposed to be developed among the youths and possibly carried over to the national and international levels of competition sometimes which the youth make a career out of it.

\section{SPORTS AND YOUTH RESTIVENESS}

Mankind had at one time or the other encountered challenges that pose serious threat to her existence and survival. The fact that in contemporary society, restivensss seems rampant is an issue that is not too difficult to handle if sports is employed. This position is given credence by the researcher, who asserts that sports has been seen as a major instrument for achieving the goal of unity, political stability and equality of opportunity and for circumvening situations which may give rise to social vices and conflict. Ogunbameni (2004), stated that conflict is a disagreement or discord. It could mean opposition, disagreement or quarrel on one hand and it could also imply, clash or fight on the other hand. Conflict mostly has a negative connotation but in actual sense it can be either destructive or constructive.

Youth restiveness armed or unarmed has been on a regular occurrence in our various communities and University campuses today. Youth restiveness arise when people have been deprived of their legitimate rights, maltreated, cheated, when there is no meaningful development, lack of employment and political instability or electoral crisis, and every disrespect to norms and traditions. These restive youths had taken to armed robbery, joined secret cult and are living an unpleasant lifestyle.

The assertion is lent credence by Omokhunu (2012), who reported that:

Studies have shown that a number of factors are responsible for violent conflict in Nigeria which are poverty, unemployment, religious intolerance, ethinic rivalry, growing acculturation and resource control.

As it is always said, no meaningful development can be made in an atmosphere of violence and rancour, therefore for development to be effected among youths in the West African Universities, sports is a prerequisite. Discussing the potency of sports to peaceful co-existence, Senator David Mark in Ayodele (2012), states that healthy competitions in sport can reduce ethno-religious conflict. According to him, sport is a factor that brings friendship, love, peace and togetherness. Supporting this assertion, UNICEF (as cited in Bright and Melvins, 2016) defined peace as:

The process of promoting the knowledge, skills, attitudes and values needed to bring about behaviour changes that will enable children, youth and adults to prevent conflict and violence, both overt and structured, to resolve conflict peacefully; and to create the conditions conducive to peace, whether at an intrapersonal, interpersonal, intergroup, national or international level ( $p .3)$. 
From the excerpts above, it is obvious that sport is capable to instill harmony, cooperation, as well as understanding between and among members of a society.

It is obvious that individuals take care of their basic needs like the need to eat good food and healthy meals, clothe and shelter themselves and there are employment opportunities for the country's teeming youths in the street when they engaged themselves in meaning sporting activities across the region. The above views demonstrate the fact that sports can serve as solution to curb youth restiveness seemingly rocking the society.

\section{YOUTH SPORTS AND CRIME CONTROL}

Sports plays a vital role in socialization process of the youths. Morakinyo posits that sports is a social phenomenon that has grown from its humble beginning of being an entertainment and recreation partime to becoming a viable and prominent business phenomenon that could no more be ignored in the social, political and economic environment of any nation. Parents, no doubt in most communities are the only ones assigned the responsibility for child upbringing in desirable directions, by supervising, teaching, encouraging and disciplining children as they go through the maturational stages. No wonder Tella (2003), asserted that parents play an invaluable role in laying the foundation for their children learning and achievement. In line with this assertion Ryan (2005), opined that adolescents making the right choice in life is positively related to having parents who ensure rules at home. The implication of this is the assumption that parents have a powerful impact on the behaviour children develop later in life which may be acceptable or anti-social behaviour (Alika \& Onomiroro, 2016:141).

Bernard (as cited in Alika and Onomiroro, 2016) is of the view that anti-social behaviours are disruptive acts characterised by covert and overt hostility and intentional aggression towards others. He further asserts that it includes repeated violation of social rules, defiance of authority and of the right of others, deceitfulness, theft and reckless disregard for self and others.

In Nigeria and other West African countries, there had been recent upsurge in adolescent crime, especially our educational sector. Ajake (2010), in line with this assertion points out that "the manifestation of anti-social behaviour by secondary school adolescents has been a problem in the Nigerian school settings". Some of those adolescents indulge in cultism, stealing, kidnapping and bullying, among others. A society with disgrunted, aggressive and adolescents who exhibit anti-social behaviour may find it difficult to progres technologically, socially, educationally and economically. For this adolescent youths to develop their potentials and become leaders of tomorrow, there is the need to ascertain the effect of youth participation in sports on anti-social behaviour and crime control among West African Univerisities.

In the same vein, Ajimer, etal (2003:566) observed that evidence has shown that particiaption in worthwhile helps to build character and prevent crime and delinquency among the children and youths. Because sports and recreational activities have a strong appeal for children and youth, anti-social behaviour like stealing, kidnapping, cultism and drug abuse are less likely to flourish in communities where opportunities for wholesome sports and recreation are abundant and attractive. Children or young people who goes to the play ground or recreation centres on a daily basis or the girl who takes part in the composition for the drama play and is pre-occupied in co-curricular/social activity might be seeking for recognition, success and achievement. They have little need to seek such satisfaction in anti-social activities. Most delinquent and criminal acts are committed during leisure hours to get the means for the enjoyment of leisure. The law enforcement agencies have testified from their experiences that 
most delinquency and crime result from inadequate recreation opportunities. Therefore, sports plays a major role in crime preventing in the life of children, youth and adult.

\section{YOUTHS CHARACTER DEVELOPMENT IN SPORTS}

It is quite obvious that youth participation in active sport and recreational activities can allow him to develop some character traits to be able to cope with life challenges. Laoye and Ackland (as cited in Uzor, 2016:4) identified some of the character traits developed by the youth which include:

Team Spirit: This is an aspect of co-operation. Team-spirit means working together for a common end, such as scoring a goal in football. It teaches the youths to put the interest of the group before one's personal interest. Most competitive games promote team-spirit, such as relay races, as well as major team games like soccer, handball, basketball to invention but a few.

Leadership: The essential test of a good leader is the morale of the group he leads. A child at birth may have the potential to become a successful leader, but the ability to lead has to be learned. Leaders are made, not born. All youths should be given the opportunity to act as a leader in different situations in Physical Education and those youths who are destined to become leaders in later life will be given the opportunity to acquire the basic qualities of leadership.

Respect for authority: As there are leaders, so there must be followers. The ability to accept and respect the authority of a leader is a basic factor in the stability of any group, providing the authority is legitimate. Group activities and games help the youths to learn to appreciate the need for order and control under the direction of a leader. It is as important as learning how to act as a leaders.

Loyalty: This means being faithful to other people, so that they will know that you can be trusted. A loyal person will not speak badly of his friends or team mates behind their backs. Taking part in team games helps to promote loyalty, not only to the team, but to the school and the community as well.

Fair play: This means not taking advantage over other people, by such methods as cheating or by unnecessarily rough play. It should not be necessary for the referee or umpire to keep an eye on every thing that is going on in games. The youths have to learn, once the rules have been agreed they apply to every one alike, irrespective of position or status.

Impartiality: Judges referees and umpire should all possess the quality of impartiality. It means being able to pass judgment without favour to either side. The youths can learn how to act with impartiality by being placed in situations in which they have to apply the rule, such as being asked to referee a game of volleyball.

Co-operation: Group work plays an important part in the teaching of physical education. When the youths work together in a group they have to learn how to operate successfully with each other. More than any other subject, Physical Education provides a wide range of group activities, through which the teacher is able to promote a co-operative spirit among his students e.g. swimming and gymnastics, the students act as supporters for one another.

Selflessness: It follows that team spirit and selflessness go together. It is the opposite of selfishness. A selfless person is considerate to other people and is able to share and co-operate 
with team-mates. He will be prepared to listen to what other people have to say before putting forward his own point of view.

Sportsmanship: The term sportsmanship means something important and valuable, both for the individual and the group. A good sportsman is a person who is honest, loyal, straight forward and reliable. He will be a respected member of the community with a sting regard for the needs and interest of others. It is through active participation in games and sports, that quality of good sportsmanship can be developed and fostered in individuals.

Forbearance: Forbearance enables the individual to endure, and overcome, the strains and tensions of life. In Physical Education it can be fostered by encouraging the youths to train and practice hard even though they might feel like giving up. The champion athlete has to train for many hours at a time, in order to improve his performance and to prepare himself for competitions.

\section{CHALLENGES FACING YOUTH SPORTS DEVELOPMENT IN UNIVERSITIES}

Uzor (2010:6) observed some of the challenges that need to be addresed in order to enure young people active participation in sports and development activities.

\section{Inadequate Instructional/Infrastructural Sport Requirement}

The factor of adequate sports facilities and equipment is an important variable among the variable that facilitate the attainment of outstanding sports performances. The dearth in the provision of adequate, appropriate and timely instructional or sports requirements in all the three tiers of governments (Federal, State and Local Government) are a big problem to youth sport development in Nigeria and in other West African countries. Some of these facilities at our universities of higher learning are substandard and the standard ones after the hosting major games like Nigerian University Games Association (NUGA), Nigerian Polytechnic Games Association (NIPOGA) waste in a state of disrepair. Sadly, for the country Musa Dogo (2009) noted that the available sports facilities at our Stadium in Lagos, Ibadan, University of Maduguri and others have been left to waste in a state of disrepair.

\section{Poor Funding of Sports}

The Federal and State government fail to accept primary responsibility of funding of sports for youth development all around the countries. And responsibilities had not been discharged through regular and adequate budgetary allocations to the sector and through the mobilization of additional resources in the private sector of youth sports development programs.

\section{Inadequate Sports Programs}

The factor of adequate sports programs is one of the problems facing youth sports development in WAUG. Both teaching and training programs are necessary to improve youth sports skills and provide ample opportunities for the youth to improve their level of aspirations. The teaching programs lack integration and implementation of sports policies and when the training programs too are not motivational, supportive, and challenging with opportunities to express oneself, lack of interest in participation sets in.

\section{Poor Research and Planning}

The Physical Educational teachers depend largely on research for their academic growth. The effective planning and implementation of youth sports development programmed depend largely on research and projects based on the availability of reliable and valid data. Nigerians are yet to plan and conduct reliable research on youth sports issues and publishing report and proceedings resulting from such researches and seminars. And Local utilization of research 
products in Nigeria and others is unpopular hence most research appear unmotivated for further research.

\section{Poor Implementation of Sports Policy}

There is a lot of challenges facing sports policy in Nigeria and West African universities. The federal, state and local governments has ignored out-rightly to adopt the implementation strategies of the National sports policies across the West African Region. Financial support, training and facilities need to be providing at all levels in order to ensure young peoples, active participation in decision-making and sports development programs.

\section{Poor Scouting and Identification of Talents}

The step in the process of scouting and identification of talents is the detection of talent in students not yet involved in regular training. University setting is the last level of student participation in intramural or extramural ends and the maturity level begins. Sadly among the slogan of "catch them young" have become mere passwords as far as scouting for talents is concerned in the university sports. This is because basic pre-requisites like coaches, training facilities and comprehensive training programmes which are needed to groom these young talents to maturity are lacking. The next option is to hire non-bonafide students in order to win at all cost.

\section{CONCLUSION}

In conclusion, it is clear that for sports development to be feasible in West African Universities, the youth must be actively involved and participate in sports. They are the life-wire of the nation. Since sports is regarded as a vital means of achieving national development. Therefore the youths through sport should be giving an opportunity to develop skills for a better youthful society.

\section{RECOMMENDATIONS}

Based on the prevailing conditions of youth sports development among Universities in the West African Region, the following recommendations were made:

1. The three tiers of governments should be able to systematise sports policies, programmes and projects that can bring about an appreciable level of development in our youth. Most importantly, cater to their needs and provide them education, employment and recreational activities and sports in a healthy and competitive environment.

2. There should be a collaboration between the government, private sector and the University authority to provide, supervise and maintain sports facilities and equipment playground, recreation, parks and gardens at all levels of our educational system.

3. The university management in conjunction with federal and state governments should accept and perform their primary responsibility of funding sports for youth development.

4. Basic physical activity courses should be introduced and make compulsory in the universities as general studies (GS) to help involve every student in active sports participation for talent hunt in the university.

\section{References}

Ayodele, A. (2012). Sport can end ethno-religions conflicts David mark.www.tribine.com.ng/indext. Php ports/363.

Deemua, G.A. \& Ohaka, P.C (2018). Coaches leadership styles as correlate of interscholastic sports participation among secondary school students in Rivers East Senatorial District of Rivers State. Intertional Journal of Scientific Research in Education.11(3B) 636-1644. 
Egu, R.H.N. \& Ukandu, O.C.C. (2016). Reviving the interest International Journal of scientific in skill acquisition in primary school pupils in Nigeria. Trends in Educational Studies. 9(172) 236-242.

Encarta Dictionary (2009). en.softonic.com>windows $>$ science \& education software $>$.General. retrieved $06 / 12 / 2005$.

Ivowi, U.M.O. (2001). Practical application of STS approch to science and technology education for successful implimentation of UBE programme. In Teefino, A.E. Idasajgu, M.A. and Obasi,F.E. (eds). Peoceedings of STAN, STS workshop and practical application of CTS to science and technology education for successful implementation of UBE programm 16-21 May, Ibadan STAN 33-39.

Musa Dogo, A.U. (2009) sports development in Nigeria and the national sports festivals (1993-2009) changes of vison 2020 zaria: The Amadu Bello University press limited.

Okanezi, B.\& Hanachor, M.E. (2016). Peace education for the achievement of sustainable community development in Rivers State. Trends in Educational Studies 9(1\&2), 264-273.

Omokhunu, (2012). Solution to insecurity in Nigeria is dialogue, says Obansanjo: major reason for violence is ignorance. The Nation 7(2117), 5.

Ogunabameni, O.A, (2004). Organisation dynamics. Ibadan: Spectrum Books ltd.

Ajake, U.E. (2010). Child rearing style and brutal behaviour in Cross River State. Journal of Counselling Association of Nigeria, (3) 142-146.

Alika, I.H. \& Onomiroro, D.O. (2016). Educational level of parent and home enviroment as correlates of anti-social behaviour among adolescents in Sapele Local Government Area of Delta State Nigeria. Journal of Institute of Education, University of Port Harcourt, 9(1\&2), 141-146.

Tella, T. (2003). Parental involvement, home background and school environment as determinants of academic, achievement of secondary school students in Osun State, Nigeria. Journal of Cross-Cultural Psychology and sports facilitation, 5(2)42-48.

Ajimer, S., Jagta, S.U., Jagdish, B., \& Rachpal, S.B. (2003). Essential of physical education. New Delhi: Kalyani Publishers.

Ryan, T. (2006). Using information in education. http://www.parent//involvement/html. Retrieved 20th, March 2015.

Ryan, S.W. (2002). Why do more women than men want to earn a four year degree? Exploring the effect of gender social origin and capital in educational expectations. Journal of Higher Education, 82(1)1-32. Deemua, G.A. \& Ohakwu, P.C. (2018).

Oputeh, M. (2015). Nigeria: sports and youth development. Retrieved October 25 th 2018 from http://youthsdigest.com/2015/04/22/nigeria-sports-and-youth-development/.

Uzor, T.N. (2010), Sports empowerment of the youths to accomplish vison 2020. The Nigeria Journal of Reserch and production 16(2)1-10. 